\title{
Charcot and vascular Parkinsonism
}

\section{O parkinsonismo vascular de Charcot}

Hélio A. G. Teive', Francisco M. B. Germiniani', Renato P. Munhoz²

\begin{abstract}
Jean-Martin Charcot (1825-1893), recognized as the founder of Neurology and the first formal teacher of nervous system diseases, died on August 16, 1893, from acute pulmonary edema secondary to myocardial infarction. In his last years, there were several descriptions of his gait and posture disorders, suggesting the diagnosis of "lower-half parkinsonism" due to cerebrovascular disease.
\end{abstract}

Keywords: Parkinson's disease; brain diseases.

\section{RESUMO}

Jean-Martin Charcot (1825-1893) pode ser reconhecido como o fundador da Neurologia, bem como o primeiro professor de doenças do sistema nervoso. Ele morreu no dia 16 de Agosto de 1893, em decorrência de edema agudo de pulmão, secundário a infarto agudo do miocárdio. Nos últimos anos da vida de Charcot, ocorreram várias descrições de anormalidades da sua marcha e da sua postura, sugerindo o diagnóstico de parkinsonismo vascular.

Palavras-chave: doença de Parkinson; encefalopatias.

Jean-Martin Charcot (1825-1893) is widely recognized as the founder of Neurology as well as the first formal teacher of nervous system diseases ${ }^{1,2}$. His contribution to neurology is outstanding, describing several diseases, including Charcot-Marie-Tooth disease, amyotrophic lateral sclerosis, and multiple sclerosis, among others ${ }^{1,2}$. During his tenure at the Paris Medical School as professor of diseases of the nervous system (from 1882 to 1893), Charcot suffered from chronic low back pain and angina pectoris attacks ${ }^{1,2,3,4,5}$. He died on August 16, 1893, from acute pulmonary edema secondary to myocardial infarction ${ }^{1,2,3,45}$. The aim of this historical review is to analyze clues that may indicate the diagnosis of vascular parkinsonism over the course of Charcot's later life.

\section{CHARCOT'S HEALTH PROFILE}

Biographical data about Jean-Martin Charcot (Figure) demonstrates that, overall, he led an unhealthy life. He had a short stature, short neck, was obese (predominantly in the abdominal area), had poor physical hygiene, was sedentary with a voracious appetite, in addition to having been a chronic heavy smoker (especially cigars), combined with a disturbed sleep cycle due to intense intellectual activity

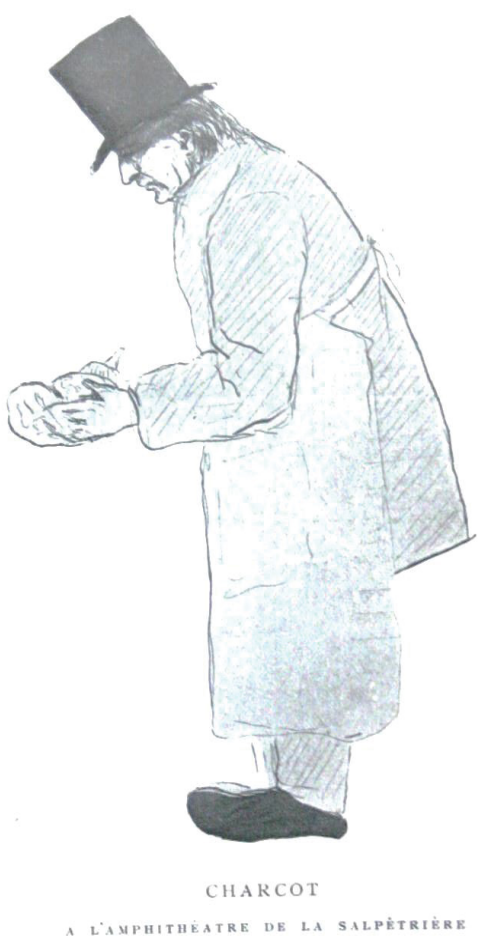

(Extracted from Google Images, neuro-caricatures-eu, May, 25th, 2016) Figure. Jean-Martin Charcot (1825-1893).

\footnotetext{
¿Universidade Federal do Paraná, Hospital de Clínicas, Departamento de Medicina Interna, Unidade de Distúrbios do Movimento, Serviço de Neurologia, Curitiba PR, Brasil;

${ }^{2}$ University of Toronto, Toronto Western Hospital, Movement Disorders Centre, Toronto, ON, Canada.

Correspondence: Hélio A. G. Teive; Rua General Carneiro; 1103/102; 80060-150 Curitiba PR, Brasil; E-mail: hagteive@mps.com.br

Conflict of interest: There is no conflict of interest to declare.

Received 13 June 2016; Received in final form 08 November 2016; Accepted 07 December 2016.
} 
stretching late into the night ${ }^{1,2,3,4,5}$. Charcot's personality was defined as authoritarian, shy, taciturn, skeptical, brusque, gloomy, and competitive $e^{1,2,3,4,5}$. Bounduelle considered that Charcot's silence hid "a prelude to an explosion of rage" He suffered from chronic low back pain and intermittent episodes of precordial discomfort, suggestive of coronary insufficiency, associated with anxiety ${ }^{3,4,5}$. Modern literature confirms the relationship between anxiety, anger and mortality risk among patients with myocardial infarction.

\section{CHARCOT'S CORONARY ATHEROSCLEROTIC DISEASE}

During the new year's eve of 1890, at the age of 65 , Charcot had an acute episode of precordial pain, and Professor Potain, a famous Parisian clinician, confirmed the diagnosis of angina pectoris, suggesting a potentially fatal outcome within two years ${ }^{1,2}$. Guillain, in his famous biography on Charcot (J-M Charcot. His Life - His Work, edited by Bailey in the USA), wrote about this cardiovascular episode, citing Léon Daudet's memoirs "Charcot was dining in his house, with several friends, including Louis Pasteur, and suddenly felt a violent constriction around the heart. He left the table, became terribly pale, and his handsome features revealed intense pain". Professor Potain, a famous clinician, who lived across the street from Charcot's house on Boulevard Saint Germain, examined him extensively and prescribed medication ${ }^{1}$. After that, Professor Potain shared with Daudet a fateful prognosis "Charcot knows what ails him, but I succeeded in reassuring him a little - two years

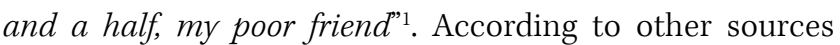
published by Guinon and Souques in $1925^{4,5}$, both entitled Charcot Intime, there was no mention of other vascular arterial diseases suggestive of arterial insufficiency episodes, such as intermittent claudication, a condition previously described by Charcot himself ${ }^{6,7}$, or transient ischemic attack (cerebrovascular disease).

\section{CHARCOT'S VASCULAR PARKINSONISM}

In the last years of his life there were several descriptions, one of them from his assistant Souques, of Charcot's gait and posture disorders (shuffling, apraxic gait with "petit pas", and flexed posture of the trunk), mimicking Parkinson's disease ${ }^{1,2,3,4,5}$. Interestingly enough, there was no reference to the presence of upper limb symptoms, or tremor (typical pillrolling rest tremor), suggesting the diagnosis of "lower-half or lower-body parkinsonism" indicative of vascular parkinsonism ${ }^{1,2,3,4,5}$. In 1925, Garrison described Charcot as "so sedentary that his very gait was regarded as that of a man who could not walk properly because he had forgotten how. With bent back and head thrust forward, he seemed to propel himself by short, quick, shuffling steps. Toward the last, when he mimicked the propulsion in paralysis agitans, he seemed to be a patient. ${ }^{8}$

Critchley was a pioneer in this topic, describing, for the first time, "arteriosclerotic parkinsonism" in $1929^{9}$. Nowadays, vascular parkinsonism represents the second most common cause of secondary parkinsonism, resulting from cerebrovascular disease ${ }^{10}$. Normal pressure hydrocephalus represents another important cause of secondary parkinsonism ${ }^{10}$. Vascular parkinsonism is characterized by the presence of bradykinesia and rigidity, predominantly in the lower limbs, associated with a peculiar pattern of gait and postural disorder, frequent falls, cognitive decline, pyramidal signs, and other focal deficits ${ }^{10}$. Vascular parkinsonism has remained a controversial clinical entity and brain MRI is the most important paraclinical test for the diagnosis, demonstrating microvascular brain disease, with subcortical white matter lesions (leukoaraiosis), and lacunar infarcts ${ }^{10}$.

In conclusion, we speculate that Professor Charcot may have presented with features indicative of vascular parkinsonism in his last years of life, associated with other vascular disorders and risk factors (angina pectoris, probable cerebrovascular disease and, eventually, myocardial infarction).

\section{References}

1. Guillain G.J-M. Charcot. 1825-1893: his life- his work. New York: Paul B. Hoeber; 1959

2. Goetz CG, Bonduelle M, Gelfand T. Charcot: constructing neurology. New York: Oxford University Press; 1995.

3. Bonduelle M. The intimate Charcot. Rev Neurol (Paris). 1994:150:524-8.

4. Guinon G. Charcot intime. Paris Medical. 1925:511-6.

5. Souques A. Charcot intime. Presse Medicale. 1925:693-8.

6. Lacombe M. [The history of intermittent claudication due to arterial disease]. Ann Chir. 2005;130:440-4. French. https://doi.org/10.1016/j.anchir.2005.03.008
7.

Teive HAG, Munhoz RP, Barbosa ER. Little-known scientific contributions of J-M Charcot. Clinics. 2007;62:211-4. https://doi.org/10.1590/S1807-59322007000300003

8. Garrison FH. Charcot. Int Clin.1925;35:244-72

9. Critchley M. Arteriosclerotic parkinsonism. Brain. 1929;52:237-40.

10. Munhoz RP, Werneck LC, Teive HA. The differential diagnoses of parkinsonism: findings from a cohort of 1528 patients and a 10 years comparison in tertiary movement disorders clinics. Clin Neurol Neurosurg. 2010;112(5):431-5. https://doi.org/10.1016/j.clineuro.2010.03.003 